\title{
Knowledge, Perceptions and Attitudes of Islamic Scholars Towards Reproductive Health Programs in Borno State, Nigeria
}

\author{
Mairiga AG., ' Kyari. O., ' Kullima A., ' Abdullabi H. ${ }^{1}$
}

\begin{abstract}
Some reproductive health policies and activities of international development organizations continued to be criticized by some religious groups. Such criticisms can be serious obstacles in the provision of reproductive health and rights information and services in many communities. This study was conducted to find the knowledge, perception and attitude of Islamic scholars on reproductive health programs and to get some suggestions on the scholars' role in the planning and implementation of reproductive health advocacy and programming. The data were collected by in-depth interview with representative sample of selected Muslim scholars in and around Maiduguri town in Borno State, Nigeria. All the scholars had vague or no idea of what reproductive health is all about. When they were explaining reproductive health, most of the scholars mentioned some of the rights of women especially the need for maintaining the good health of women and their children as reproductive health. Even though they have poor knowledge, all the Muslim scholars interviewed believed that reproductive health is an essential component of healthy living and the programs of the international development organizations are mostly good, but they have reservations and concern to certain campaigns and programs. Scholars that promised their contributions in enhancing reproductive health have a common condition for their continuous support to any international development organization or reproductive health program. Conformity to Islamic norms and principles are prerequisites to their loyalties. The scholars also advised the international development organizations on the need to identify themselves clearly, so that people know from where they are coming, what are their background, and the program that they want to do and the reasons for doing the program in the community (Rev Afr Santé Reprod 2007; 11[1]:98-106).
\end{abstract}

\section{RÉSUMÉ}

Connaissance, perceptions et attitudes des savants islamiques envers les programmes de la santé de reproduction dans l'Etat de Borno, Nigéria Certains politiques et activités des organizations internationales pour le développement concerant la santé de reproduction font toujours l'objet de la critique de la part de quelques groupes religieux. De telles critiques peuvent constituer d'importants obstacles dans les prestations des services de la santé de reproduction et de l'information sur les droits dans plusieurs communautés. Cette étude a été menée pour identifier la connaissance, la perception et l'attitude des savants islamiques sur les programmes de la santé de reproduction et pour obtenir des suggestions sur le rôle des savants dans la planification et la mise en oeuvre du plaidoyers et de la programmation de la santé de reproduction. Les données ont été receuillies à l'aide d'une interview à fond avec un échantillon représentatif des intellectuels islamiques selectionnés dans la ville de Maiduguri et à l'alentour dans l'Etat de Borno, Nigéria. Tous les savants avaient une idée vague et parfois aucune idée de ce que représente la santé de reproduction. La plupart des savants, tout en expliquant la santé de reproduction, ont mentionné certains droits de la femme surtout la nécessité de maintenir la bonne santé de la femme et ses enfants comme étant la santé de reproduction. Bien qu'ils aient une faible connaissance de la santé de reproduction, tous les savants islamiques qui ont été interviewés ont cru que la santé de reproduction est un constituent important d'une vie saine et que les programmes des organizations pour le développement international sont bons dans la plupart des cas, ils ont leurs réserves et leurs soucis en ce qui concerne certains programmes et campagnes. Les savants qui ont accepté de contribuer à la promotion de la santé de reproduction ont une condition commune pour leur soutien continu des programmes d'une organisation pour le développement international ou de la santé de reproduction. Leur fidelité est fondée sur la conformité aux normes et principes islamiques comme des conditions préalables. Les savants conseillent les organisations pour le développement international sur la nécessité de s'identifier clairement, pour que les gens sachent d'où elles viennent, leur milieu professionnel et le programme qu'elles veulent mettre en place et les raisons pour justifier les programmes dans la communauté. (Rev Afr Santé Reprod 2007; 11[1]:98-106)

KEY WORDS: Islamic scholars, Reproductive bealth programs, International development organizations

${ }^{1}$ Department of Obstetrics and Gynaecology, University of Maiduguri Teacbing Hospital, P. M. B 1414, Maiduguri, Nigeria

Correspondence: Dr. Abdulkarim G. MAIRIGA Department of Obstetrics and Gynaecology, University of Maiduguri Teaching Hospital, P. M. B 1414 Maiduguri, Nigeria Telno: - 23408023726622 E-mail:-dragmairiga@yahoo.com 


\section{Introduction}

Reproductive health is a state of complete physical, mental and social well-being and not merely the absence of disease or infirmity, in all matters relating to the reproductive system and to its functions and processes. Reproductive health therefore implies that people are able to have satisfying and safe sex life and that they have the capability to reproduce and the freedom to decide if, when and how often to do so. Implicit in this last condition are the rights of men and women to be informed and to have access to safe, effective, affordable and acceptable methods of family planning of their choice, as well as other methods of their choice for regulation of fertility which are not against the law, and the right of access to appropriate health-care services that will enable women to go safely through pregnancy and childbirth and provide couples with the best chance of having a healthy infant ${ }^{1}$.

The international conference on population and development (ICPD) held in Cairo in 1994 represents a significant shift in the world's perception of population dynamics. For the first time, the conference not only focused on population but also on development ${ }^{2}$. The concept of sexual and reproductive health and right was firmly put in place at the Cairo conference. During that conference, representatives of government of 180 countries and thousands of delegates from many civil society organizations met (a total of 10, 757 registered participants). The outcome of that conference was a consensus document containing a 20-year program of action (till 2015) for addressing population and development issues ${ }^{3}$. In the past a great deal of policies and intervention in the field of population was focused on achieving demographic targets, the ICPD underscored the synergistic relationship between population and development. It built on the debates and lessons learnt from the two previous international population conferences held in 1974 in Bucharest and in 1984 in Mexico ${ }^{4}$.

African Journal of Reproductive Health Vol. 11 No.1 April, 2007
The ICPD program of action's endorsement urges governments to provide women and men with a host of services such as pre- and postnatal care, safe delivery, and treatment of infertility, reproductive tract infections, and sexually transmitted diseases. Also limited abortion services, "regulation of fertility" and host of others were included ${ }^{3}$. This shift toward a reproductive health perspective was achieved despite opposition from a handful of participants; notable among them were the religious groups ${ }^{3}$. Thirteen (13) countries (with potentially powerful religious groups) made statements expressing reservations or comments on specific chapters, paragraphs or phrases in the program, which they requested to be included in the final report of the conference ${ }^{5}$.

The United Nation Population Fund (UNFPA), the World Health Organization (WHO), International Planned Parenthood Federation and other international development organizations make the protection and implementation of reproductive and sexual health and rights central focus of their work ${ }^{6}$. However, the policies and activities of such international development organizations continued to be criticized by some religious groups. Such criticisms can be serious obstacles in the provision of reproductive health and rights information and services in many communities.

Most of the components of reproductive health are not new to Islam and the Muslims. Even though you find differences in understanding and interpretations but the point is clear, that the components of reproductive health and rights are enshrined in Islamic jurisprudence hundred of years before the Cairo conference. Many great Muslim scholars had written extensive treaties on most of the components of reproductive health. But the most controversial components are the issues to do with contraception and abortion. Some of the great scholars that wrote treaties on these controversial topics include Abu Hamid M. al-Ghazali (d. 
1111) ${ }^{7}$, Ibn Hazm, who lived in Islamic Spain (d. $1063)^{8}$, and recently, Abd El-Rahman al-Awadhi ${ }^{9}$ and Azizah Y. al-Hibri ${ }^{10}$. All these showed how Muslim Scholars had great interest on reproductive health issues. But is the situation the same in our community, especially a society that is predominantly Muslims and has an important historical legacy of being the nucleus of an Islamic empire (of Kanem-Borno).

\section{Objectives:}

The objectives of this study were to find the knowledge, perceptions and attitude of Islamic scholars on reproductive health programs in Borno state, and to get some suggestions on their role in the planning and implementation of reproductive health advocacy and programming.

\section{Study Area:}

Borno State occupies the greater part of the Chad Basin and is located in the Northeastern corner of Nigeria. The capital of the state is Maiduguri. Borno state covers an area of 116,589 sq kilometers and the population of the state was 3,362,351(2002 FOS est.)- $64.37 \%$ rural populace - $35.63 \%$ urban populace ${ }^{11}$. The main languages spoken in the area include English (official), Hausa, Kanuri, Shuwa, Babur/Bura, and Marghi. Predominantly the inhabitants are Muslims. Borno has an important historical legacy of being the nucleus of the Islamic empire of Kanem-Borno, and to date has continue to be a center of Islamic education and scholarship.

Available statistics show that the reproductive health situation in this area is poor, compared to any part of Nigeria. The crude birth rate was 44.5 per 1,000 populations, Total fertility rate of 7 per 1,000 women ${ }^{12}$ and maternal mortality ratio of 1,549 per 100,000 live births ${ }^{13}$. With these demographic and health indicators, It is not surprising the Nigerian HIV/AIDS and Reproductive Health Survey (NARHS) of 2003 found only $2 \%$ of women in this region using modern contraceptive ${ }^{14}$.
In an effort to control such poor reproductive health conditions, many international development organizations such as UNICEF, WORLD BANK, WHO, IFAD, IPAS have sited many reproductive health programs in this area. However, Islamic leaders, who have greater influence on the lives of this community, are rarely involved in the crusade. Consequently, these influential leaders usually become the main constraints on the implementation of reproductive health programs in this region.

\section{Methodology}

Target group of this study was the Muslim scholars in Borno state, both those who were known or who were working with international development organizations and those that were not. Learned Muslim women from Islamic women's organizations were also our targets of in-depth interview. Twenty (20) Muslim scholars - 15 male and 5 female were interviewed using an open-ended questionnaire. Ten Muslim scholars ( 7 male and 3 female) were drawn from those who were working with or were known by international development organizations (e.g. WHO, UNICEF, UNFPA) in their activities. And another 10 (8 male and 2 female) were drawn from those who never had such privilege. The interviews were conducted in a local language (Hausa). All interviews were audiotape-recorded and extensive notes were taken during the interviews, and these were employed when the tapes were reviewed and transcribed. The Questions for the interview were as follows:

A. Muslim scholars known or working with International development organization in RH.

a) What do you understand by reproductive health?

b) From your experience in working with this organization (name the organization), what do you like in its activities/ policies?

c) From your experience in working with

African Journal of Reproductive Health Vol. 11 No.1 April 2007 
this organization (name the organization), what do you NOT like in its activities/ policies?

d) How do you think you have benefited from being involved in the activities of this organization?

e) Do you believe that the views of the community have changed towards you because of your involvement in the program of this organization?

f) Do you believe that the views of your colleagues have changed towards you because of your involvement in the program of this organization?

g) Can you give suggestions on improving the organization's programs in our community?

B. Muslim scholars NOT known or working with International development organization in reproductive health $(\mathrm{RH})$.

a) What do you understand by reproductive health

b) Do you know any international development organization working in the area of $\mathrm{RH}$ in our community?

c) Have you ever been contacted to participate in any international organiza-tion's $\mathrm{RH}$ activities?

d) Have you ever participated in such $\mathrm{RH}$ activities?

e) Will you participate in such development activities ( $\mathrm{RH})$ if requested to do so?

f) What are your reservations in working with such organizations?

g) What are your concerns in working with such organizations?

h) What are the advices you will give such organizations in planning and implementing their activities in our community?

i) What are the advices you will give other Muslin scholars who are working with such organizations?

African Journal of Reproductive Health Vol. 11 No.1 April, 2007

\section{RESULTS}

Knowledge of the Muslim scholars on reproductive bealth and reproductive health programs in Borno state

Except for one scholar (Who surprisingly has never worked or known by any international organization), all the rest had a vague or no idea of what reproductive health is all about. The scholar that knew reproductive health was a $\mathrm{PhD}$ student in Arabic and Islamic studies and a principal of an Islamic secondary school, probably that assisted him to learn about reproductive health. While for the rest of the scholars, when explaining reproductive health, most of the scholars mentioned some of the rights of women especially the need for maintaining the good health of women and their children. One scholar explained reproductive health as: - "Reproductive Health, according to Islam is a wholistic concept that involves the family, the wife, husband and children and other people living in the house even the animals that live in the house, their health fall within Reproductive Health. This is because any of them that is affected health wise, it will affect others psychologically"

Yet another scholar (who has never worked with any international organization), felt there was a difference between Islamic and medical concepts of reproductive health and he explained the differences between the two as follows: - "The difference is quantitative; you know in Islam, reproductive health means the rules of taking care or maintaining the family in all aspect such as religion, iman (i.e. faith), ideology, health, feeding and their clothing. All these we consider them as part of reproductive health. All are responsibilities of the husband as the leader of the house. While from the medical view, the way I understand, when we say reproductive health, we restrict it to the drugs of immunization, living with one wife because there are things that are happening in the country etc. This is restricted to these things only". As regards to presence of international development organizations working on reproductive health in the community of Borno state, all were aware 
of some or even worked with some of these organizations. Notable among the international development organizations were UNICEF, Pathfinder International, WHO, and development Research and Project Center (dRPC). Those scholars that had never been contacted by these international development organizations to contribute in reproductive health programs use to see the advocacy activities of such organizations only in the television, or hear them in the radio. One scholar, who never worked with any international organization, mentioned: -

"I used to see some of these organizations in the television paying courtesy visits to some government officials e.g. commissioner of health, or campaigning for immunization. We see them far, far away, i.e. not coming near us".

\section{Perceptions of the Muslim scholars on reproductive health and reproductive health programs in Borno state}

All the scholars commended the activities of these international development organizations. They pointed that the organizations deserve commendations because they help humanity in various aspects of human developments. A scholar, who never worked with any international organization, even indicated that such organizations' activities are Islamic as the Prophet has commended the nature of their activities. He said: - "I cannot mention any organization by name, but I know there are many such organi-zations as it's clearly mentioned in the Qu'ran that such organization will be present. That such organizations' activities are Islamic as the prophet said, "the best of human are those that benefit others"- this statement did not specifically refer to Muslims only, but even the non-Muslims".

All those who worked with these organizations mentioned that they benefited in one way or another, most mentioned capacity building (material and information, education, communication) and none of them mentioned financial benefits.
Even though all the scholars commended the activities of these international development organizations most of them had some reservations or concern on some of the activities of these organizations. The activities or campaigns the scholars had reservations included the use of condom in any form, teaching of sex educations, immunization and lack of consideration for cultural and religious values. For those who were working with international development organizations, the main concerns were the donordriven and culturally and/or religiously-insensitive nature of the programs. One of the scholars, who was a female scholar and has been working with an international organization, said: "Nothing much, but the fact that they have guided programs. They guide you to doing it and no free hands to design your own programs to suits your ideologies, so that you can carry out (the program) the way you like it and get results". Yet another scholar who had worked for an international organization echoed: - “. . but there are some issues that they do not seems to understand about dealing with people from the perspectives of a cultural background, our ideas, beliefs and things that matter to our lives. If they will take time to understand this basic believes of our communities, I believe their work will be much easier for them".

All the scholars that were working or had worked with any international development organizations felt that the views of the community and their colleagues had not significantly changed because they were working with such organizations. This, they attributed to the fact that their programs were people-oriented and those making opposition were the minority and usually with little enmity. A female scholar narrated: "Those people that do not like the international organization tell us their views about the organizations but there is no hatred, they only try to discourage us from working with the international organizations".

African Journal of Reproductive Health Vol. 11 No.1 April 2007 
Attitudes of the Muslim scholars on reproductive health and reproductive health programs in Borno state

All the Muslim scholars interviewed believed that reproductive health is essential component of healthy living and the programs of the international development organizations are mostly good, but they have reservations and concern to certain campaigns and programs. With the exception of one scholar (who had never worked with any international organization), all indicated their willingness to contribute and actively enhance reproductive health in our community whenever requested to do so. The scholar that declined to give his contribution directly said; "No, I will not agree. This is because of much work I have at hand, which I don't want to abandon, I teach my wife, my children, my students, I do some research and I am a civil servant. These are so much on me that I cannot be opportune to add more work to myself. Beside that, the truth is, such organizations mostly, possibly because I am ignorant about them, I fear them. This is because there are many organizations in the world not only health-based, but many we can see and read about. These organizations their policies mainly are far away from Islamic principles".

In contrast, all the rest believe that it is necessary to contribute in enhancing reproductive health of a community. One of such scholars, who had never worked for any international organization, narrated "Yes I will, because the Prophet said "help one another in doing good and avoid helping one another in doing bad things. Everyone that comes to me for the development of my community or Islam, especially reproductive health, I will agree and I will do my best, as if I refuse God will query me over my refusal to help in developing my community or the Islamic ummah (i.e. community)". The scholar continued "My concerns are not that they are either whites or from the west or must be Muslims or from the

African Journal of Reproductive Health Vol. 11 No.1 April, 2007
Arab countries. Any human being who ask me to contribute in human development I will, even if a monkey can do human development and request me to contribute my quota, I will do so because ideologically we have no differences".

To buttress this point further another scholar, who has been working for an international organization, added "...Islam works with the obvious features of people or organizations, we cannot work with assumptions. Everything should be considered good as the work they intend to carry out. But at any point in time you discover mistakes then you can point out such mistakes. Islam does not teach doubts and speculations". It is pertinent to note that even those scholars that promised their contributions in enhancing reproductive health have a common condition for their continuous support to any international development organization or reproductive health program. Conformity to Islamic norms and principles are prerequisites to their loyalties. "If you are to work with such organization, you should be alert. Whatever you do or ask not to do must be weighed against Islamic principles and norms. If it tallies with Islamic injunctions, you take it but if not you leave it, but point to them that it is not correct".

\section{The advice Muslim scholars gave in enhancing reproductive health programs in our community}

The following advices were suggested by the Muslim scholars, to the international development organizations, in enhancing reproductive health programs in our community.

a. The Organizations need to identify themselves clearly, so that people know from where they are coming what are their background, and the program that they want to do and the reasons for doing the program in the community. One of the scholars, who had been working with an international organization, cautioned: - "These organizations 
should know that they are meeting or going to work in a community already programmed with certain ideologies and policies. Not a community without senses of direction. Therefore, their messages should be clearly spelt out, without hiding any agenda or ideas especially by passing through God fearing leaders, who will in turn explain to the community the organization's aims and objective".

b. The organizations should know the priorities of the people and work on the people problems/priorities. A female scholar, who had been working for an international organization, suggested that "If they have certain concepts or ideas that they feel are suitable for some of our problems then they should make people understand these ideas and let the people see the impact or ideas themselves. If the ideas are not made clear, then it will be difficult for people to accept".

c. For sustainability, a lot of enlightenment and sensitization of the community leaders and philanthropists are needed. This can be done according to a scholar, who worked for an international organization, by "Patience and endurance from these organizations. They should be patient and endeavor because some of the resistance they face in our community is because of previous bad experiences met from similar international organizations. And therefore, there must be some people that will oppose their activities". A scholar, who also had been working with an international organization added, "The best facts that will help the organizations are the benefits of their programs and no harm to the community at any point in time. Once the benefits are obvious every body will accept them, but if there is harm to certain members of the community then they will ever get resistance".

d. Programs should be situated at the rural areas where problems are more rather than the cities where many programs are currently sited. The following advices were suggested by the Muslim scholars, to their colleagues working with international development organizations, in reproductive health programs.

Their advice as: -

a. The Muslim scholar must have sincerity of purpose. Therefore, they must be careful with those they are working with them.

b. They must be careful in all the activities they do. They should talk where the activities go wrong. A scholar who never worked with any international organization explained further: - "They should fear God. They should remember that there are different conspiracies and ill intentions in the world, while they may not understand. Therefore these scholars must ask such organizations in details as to their mission and activities. They should also tell the organization the truth especially when the organizations go wrong".

c. Educate the organization on Islamic principles so that their activities will not be opposing Islamic rules.

d. Educate the public on the activities of such organization. Their objectives, benefits and activities should be clearly explained, so that they can clear the activities of such organization from the wrong notions arising from our communities.

\section{DISCUSSION}

When selecting the Muslim scholars for this study we were amazed to find out that it was difficult to find independent scholars, who were working

African Journal of Reproductive Health Vol. 11 No.1 April 2007 
with any international development organization in our community. All the scholars were working or were invited by these international development organizations were associated with Islamic organizations. This I believe is an error on the side of the international development organizations for only a small proportion of the scholars belong to religious organizations that they work with, and many are not belonging to any such organizations. Therefore, involving other Muslim scholars that are not related to any Islamic organization is essential.

Reproductive health as a concept is relatively a new concept emerging, principally, after the Cairo conference ${ }^{2-4}$. However, prior to that conference, programs dealing with various components of reproductive health existed in some form almost everywhere. But they have been delivered in disparate and separate ways, unconnected to programs dealing with closely interdependent topics. For example, the objectives, design and evaluation of family planning programs were largely driven by demographic imperatives, without due consideration to related health issues such as maternal health or sexually transmitted diseases prevention and management ${ }^{4}$. The reproductive health approach aim to build on what exists and at the same time to modify the current narrow, vertical programs to ones in which every opportunity is taken to offer women and men a full range of reproductive health services in a linked way. Such an approach also recognizes that dealing with one aspect of reproductive health could have synergistic effects in its dealings with others ${ }^{15}$. Such a new approach may not be widely known, especially among our religious scholars. This could be responsible for the poor knowledge of reproductive health among the scholars studied. The poor knowledge among the scholars, even those working with international development organizations, indicates the need for these international development organizations to educate the scholars. This education will not only enlighten the scholars but also bring them together, thus creating intimacy between the international development organizations and Muslin scholars.

In spite of the reservations and concerns expressed, the perceptions of the Muslim scholars toward reproductive health programs and the international development organizations in our community are good and encouraging. If the advice and suggestions offered by these scholars are given consideration, reproductive health programs will be a success in our community. All the scholars, except one, promised to contribute in any form, directly or indirectly. This is a golden opportunity for the international development organizations.

The attitudes of the community has not changed significantly towards those scholars working with the international development organizations, coupled with the facts that other Muslim scholars are willing to contribute their quota in the reproductive health of our community, which means that it is essential to resurrect the scholarly competition among Muslim scholars on the various components of reproductive health as was the case with their predecessors and to introduce the new integrated approach to reproductive health in the debates. The reduction in scholarly debates among the Muslim scholars could explain the poor quality and quantity of Islamic health-treaties and verdicts in our community. This is particularly the case, in the fields of reproductive health, which continue to experience challenging patterns and international modifications as the world becomes more and more technologically sophisticated.

As regards to verdicts on certain issues, Muslim scholars should make their position clear to other Muslims by appealing to legitimate jurisprudential principles. This approach would allow them to reach their desired conclusion, while at the same time utilizing full disclosure with other Muslims. It would also preserve the integrity of scholarly religious analysis, relate to the community 
on a mature and principles basis, and raise the community's consciousness while leaving room for dissenting personal decisions by the average Muslim, who are the ultimate beneficiaries of such verdicts. ${ }^{10}$ In conclusion, this study has attempted to highlight the knowledge, perception and attitudes of Muslim scholars in our community toward reproductive health. The knowledge is poor but the perceptions and attitude of the scholars to reproductive health programs are good and encouraging.

\section{Acknowledgement}

This study has been partially sponsored by Development Research and Project Center (dRPC), Kano Nigeria, and therefore we are very grateful for not only the financial support but also the initial conception of the idea and the technical advice offered for the success of the work. We are also grateful to Ustaz Abatcha and Malam Abdullahi Ibrahim for dedicating their valuable times to organizing the interviews with the scholars.

\section{REFERENCES}

1. Fathalla, MF. Promotion of research in human reproduction: Global needs and perspectives. Hum. Reprod. 1988, 3; 7-10

2. Iwere, N., Overview of topical issues in reproductive and sexual health and rights. Curriculum Review Meeting on reproductive health. Campaign Against Unwanted Pregnancy (CAUP), Lagos, Nigeria, 2001.

3. CRLP, The Cairo conference, a programme of Action for reproductive rights? Center for Reproductive Law and Policy- international program briefing. 1994.

4. Akande, EO. Components of sexual and reproductive health and rights. Curriculum Review Meeting on reproductive health. CAUP, Lagos, Nigeria, 2001.
5. ICPD, Introduction. Summary of the programme of Action of the international conference on population and development UN, New York.1994, p5-7

6. Holzner B. Nathalie K and Siti D. Reproductive rights: Framing quality of care. In, East West encounters on reproductive health practices and policies, Indonesian NGO's meet d utch organizations. Aksant Academic publishers, Amsterdam, 2002, p 17-29.

7. Abu Hamid M. al-Ghazali, 'Ihya' Ulum al-Din reprint, Mustafa al-Babi al-Halabi wa awladuhu, Cairo, 1939, vol. 2.

8. Abu Muhammad ibn Hazm, Al-Muhalla reprint, Maktabat al-Jumhuriyah al-Arabiyah, Cairo, 1970, v. 11

9. Abdel Rahim Omran, Family Planning in the Legacy of Islam. Rutledge, London, 1992.

10. Al-Hibri, AY, Family Planning and Islamic Jurisprudence. A Religious Consultation on Population, Reproductive Health \& Ethics. A paper delivered at Prepcom II of the International Conference on Population and Development at the United Nations. 1993.

11. Federal Office of Statistics. National Population census, Est., Federal Office of Statistics Abuja, Nigeria, 2000.

12. National Population Commission (Nigeria). 2000. Nigeria Demographic and health survey 1999. Calverton, Maryland. National Population Commission Pp 35-43

13. National Population Commission (Nigeria).2004. Nigeria Demographic and Health Survey 2003. MD: National Population Commission and ORC/ Macro, p 51-60

14. Federal Ministry of Health (Nigeria). National HIV/AIDS and Reproductive Health S urvey, 2003, Federal Ministry of Health Abuja, Nigeria. 2003. p 99-115.

15. Mary Stopes International, 2002. Reproductive Health Briefing packs no. 11. Internet: www.mariestpes.org.uk/paf/english-inserts.pdf

African Journal of Reproductive Health Vol. 11 No.1 April 2007 